\title{
Informing effective smokefree policies in Argentina: air quality monitoring study in 15 cities $(2007-2009)$
}

\author{
Verónica Schoj, MD, ${ }^{(1,2)}$ Ernesto M Sebrié, MD, MPH, (3) María Elizabeth Pizarro, MD, ${ }^{(1,2)}$ \\ Andrew Hyland, PhD, (3) Mark J Travers, PhD.(3)
}

\author{
Schoj V, Sebrié EM, Pizarro ME, Hyland A,Travers MJ. \\ Informing effective smokefree policies \\ in Argentina: air quality monitoring study \\ in 15 cities (2007-2009) \\ Salud Publica Mex 2010;52 suppl 2:SI57-S167.
}

\begin{abstract}
Objective.To evaluate indoor air pollution in hospitality venues in Argentina. Material and Methods. PM $_{2.5}$ levels were measured in a convenience sample of venues in 15 cities with different legislative contexts following a protocol developed by Roswell Park Cancer Institute. Results. 554 samples were collected. Across all 5 smokefree cities the mean $\mathrm{PM}_{25}$ level was lower during daytime vs. evening hours, 24 vs. $98 \mathrm{PM}_{2.5}$ respectively $(p=.012)$. In the three cities evaluated before and after legislation, $\mathrm{PM}_{2.5}$ levels decreased dramatically $(p<0.00$ I each). Overall, $\mathrm{PM}_{2.5}$ levels were 5 times higher in cities with no legislation vs. smokefree cities $(p<0.00 \mathrm{I})$. In cities with designated smoking areas, $\mathrm{PM}_{2.5}$ levels were not statistically different between smoking and non-smoking areas $(p=0.272)$. Non-smoking areas had significantly higher $\mathrm{PM}_{2.5}$ levels compared to $100 \%$ smokefree venues in the same city (twofold higher) $(p=0.017)$. Conclusions. Most of the participating cities in this study had significantly lower $\mathrm{PM}_{2.5}$ levels after the implementation of $100 \%$ smokefree legislation. Hence, it represents a useful tool to promote $100 \%$ smokefree policies in Argentina.
\end{abstract}

Keywords: tobacco smoke pollution; air quality, indoor; suspended particles; smoking/laws
Schoj V, Sebrié EM, Pizarro ME, Hyland A, Travers MJ.

Políticas efectivas de ambientes libres de humo de tabaco en Argentina: estudio de monitoreo de calidad del aire en I5 ciudades (2007-2009). Salud Publica Mex 2010;52 supl 2:SI57-S167.

\section{Resumen}

Objetivo. Evaluar la polución ambiental del sector gastronómico en Argentina. Material y métodos. Se midieron los niveles de partículas respirables $\left(\mathrm{PM}_{2.5}\right)$ en una muestra por conveniencia de establecimientos de 15 ciudades con diferente legislación, siguiendo un protocolo del Instituto de Cáncer Roswell Park. Resultados. Se recolectaron 554 muestras. En cinco ciudades libres de humo (CLH) la media de $\mathrm{PM}_{2.5}$ durante el día fue baja y menor a la observada durante la noche, 24 vs. $98 \mathrm{PM}_{2.5}$ respectivamente $(p=.012)$. En las tres ciudades evaluadas antes y después de la legislación, las $\mathrm{PM}_{2.5}$ disminuyeron drásticamente $(p<0.001$ cada una). Las $\mathrm{PM}_{2.5}$ fueron cinco veces mayores en ciudades sin legislación comparadas con $\mathrm{CLH}(p<0.00 \mathrm{I})$. En ciudades con restricción parcial, no hubo diferencia significativa entre las $\mathrm{PM}_{2.5}$ en el sector fumador y no fumador $(p=0.272)$. Los sectores no fumadores tuvieron niveles $\mathrm{PM}_{2.5}$ significativamente más altos comparados con los lugares 100\% libres de humo de la misma ciudad $(p=0.017)$. Conclusiones. La mayoría de las ciudades participantes en este estudio tuvieron niveles $\mathrm{PM}_{2.5}$ significativamente más bajos tras la implementación de leyes pro ambientes $100 \%$ libres de humo de tabaco, por lo que representa una herramienta útil para promover legislación $100 \%$ libre de humo en Argentina.

Palabras clave: contaminación ambiental por humo de tabaco; calidad del aire; partículas suspendidas; tabaquismo/leyes

(I) Fundación Interamericana del Corazón. Argentina.

(2) GRANTAHI, Tobacco Control Program - Hospital Italiano. Buenos Aires, Argentina.

(3) Department of Health Behavior, Roswell Park Cancer Institute. Buffalo, New York.

Received on: February 5, 2010 - Accepted on: May 27, 2010

Address reprint requests to: Dra. Verónica Schoj. Fundación Interamericana del Corazón Argentina. Julián Álvarez 8I3. I4I4, Buenos Aires,Argentina. E-mail:vschoj@fibertel.com.ar 
Secondhand tobacco smoke(SHS) is a combination of more than 5000 toxic chemicals and cancer causing substances due to both, exhaled mainstream smoke and particles emitted by the burning end of the cigarette. Such particles belong to the fine to ultrafine particle size range ${ }^{1}(0.02 \mu \mathrm{m}-2 \mu \mathrm{m})$. The US Surgeon General, ${ }^{1}$ the International Agency for Research on Cancer ${ }^{2}$ and the California Environmental Protection Agency $^{3}$ have shown that exposure to SHS imposes a health hazard to humans (both smokers and non-smokers) and increases their risk of disease and death. SHS has been associated with an increased risk of respiratory disease, lung cancer, acute myocardial infarction, and stroke.

Article 8 of the World Health Organization Framework Convention on Tobacco Control (WHO-FCTC) establishes the adoption of $100 \%$ smokefree policies. ${ }^{4}$ The guidelines for the implementation of Article 8 have provided clear standards regarding the enactment and enforcement of $100 \%$ smokefree laws with universal protection and the prohibition of false solutions such as designated smoking areas (DSAs) and indoor air ventilation by means of air purifiers. ${ }^{4}$

In 2006, Uruguay became the first Latin American country to implement a 100\% smokefree policy in all public places, workplaces and public transportation in accordance with the WHO recommendations. Since then, Panama (2008), Colombia (2009) Guatemala (2009), Paraguay (2010) and Perú (2010) at the national level, and Argentina, Venezuela, Mexico, and Brazil with sub-national legislation, followed the Uruguayan example. ${ }^{5,6}$

As of August 2010, Argentina is one of the few countries in Latin America that has not ratified the WHOFCTC. ${ }^{4,7}$ There is no federal smokefree policy in the country. However, Argentina became the first country in the region to implement $100 \%$ smokefree policies at the sub-national level., ${ }^{5,8} \mathrm{~A}$ high level of public support regarding the implementation of smokefree environments has been shown by a public opinion poll conducted in 2008-2009 by the Alianza Libre de Humo Argentina (ALIAR, Smokefree Alliance of Argentina). B Between 2006 and October 2009, three provinces of Argentina have implemented 100\% smokefree legislation (Santa $\mathrm{Fe}$, Tucumán, and Neuquén) and five more (Mendoza, Córdoba, Entre Ríos, San Juan and Santiago del Estero) have enacted comprehensive smokefree laws that exclude specific venues (e.g., casinos). Also, 21 cities from

\footnotetext{
* Author's personal communication. Schoj V, Population-based survey to assess the impact of $100 \%$ smoke-free environments in Argentina. Available at www.aliarargentina.org.
}

six other provinces (Corrientes, Chaco, Buenos Aires, Chubut, Río Negro and Tierra del Fuego) have enacted 100\% smokefree ordinances. Up to August 2010, about $35.9 \%$ of the total Argentinean population was covered by 100\% smokefree policies (around 14384300 of the total 40000000 inhabitants) and health benefits of 100\% smokefree legislation has been already demonstrated in Argentina. ${ }^{9}$

The tobacco industry and its allies have continuously interfered in the enactment and enforcement of effective smokefree policies in Argentina both by developing volunteer initiatives such as the Courtesy of Choice Program and by directly lobbying governmental authorities. ${ }^{10-12}$

As a result, some jurisdictions in Argentina either allow for DSAs in bars and restaurants, or exempt some venues such as casinos and bingos. The cases of the laws approved in the city of Buenos Aires (2005) and the province of Buenos Aires (2008) are examples of success of these industry efforts. Furthermore, the hospitality industry has also shown resistance regarding the implementation of 100\% smokefree policies.

As it has already been shown, restaurant and bar workers who have a higher exposure to SHS have a significantly increased risk of morbidity and mortality as compared to other workers. ${ }^{13,14}$

This study is part of the Global SHS Research Study led by Roswell Park Cancer Institute (RPCI) conducted in more than 30 countries around the world. ${ }^{15}$

In Argentina, the goal was to assess indoor air pollution among hospitality venues from cities with different smokefree policies.

The specific objectives of the study were: 1 ) to determine differences in air pollution by type of legislation; 2) to determine differences in air pollution by type of venue and time of day; 3 ) to determine differences in air pollution before and after the implementation of smokefree legislation; and 4) to use these measurements to advocate for the enactment and the enforcement of $100 \%$ smokefree legislation throughout the country.

\section{Material and Methods}

\section{Overview}

The RPCI has conducted indoor air pollution measurements in over 30 countries worldwide. ${ }^{15}$ In Latin America, Brazil, Uruguay, and Venezuela have already been enrolled in these studies. Argentina has a heterogeneous legislative setting and the federal characteristics of the political system make it possible for each province or city to have its own local legislation. In our setting there are cities with $100 \%$ or comprehensive 
smokefree legislation, with partial restriction laws and with no legislation at all.

In the cities included in our study, we evaluated the compliance of local policies where $100 \%$ smokefree legislation had already been implemented and the level of indoor air pollution in those cities with partial or no smoking restriction.

For each city, we selected a convenience sample of venues including bars, restaurants, casinos, bingos, pubs, and discos.

\section{Selection of cities and provinces and data collection}

We included cities with different types of local legislation to obtain a representative scenario of the current situation in Argentina.

The type of legislation was defined as: " $100 \%$ " with no smoking allowed in any public place, "comprehensive" with no smoking allowed in any public place with the exception of certain specific venues such as smokers' clubs, casinos and/or discos; and "partial" legislation which allows for DSAs and ventilation.

The type of hospitality venues were classified into: "bars", whose primary purpose is the sale of nonalcoholic beverages and light meals during daytime; "restaurants", whose primary purpose is the sale of food; "pubs", whose primary purpose is the sale of alcohol late at night; and "discos", whose primary purpose is dancing and the sale of alcoholic beverages late at night.

Both daytime and nighttime hours were defined as from 8:00 AM to 8:00 PM and from 8:00 PM to 8:00 AM, respectively.

Testing was completed in smoking and smokefree venues on all days of the week and at all times of the day.

Data was collected in each city from January 2007 to September 2009 and then sent to Buenos Aires to undergo a quality evaluation process before they were sent to RPCI for the statistical analysis.

For those places with $100 \%$ smokefree laws we assessed compliance of the legislation. For those cities with partial smoking restrictions we measured indoor air pollution in venues with designated smoking and nonsmoking areas to raise awareness about the inefficacy of these measures and to promote the enactment and enforcement of $100 \%$ smokefree policies. Measurements were performed in the following cities: Santa Fe and Rosario (Santa Fe), Corrientes (Corrientes), Tucumán (Tucumán), Córdoba (Córdoba) (with 100\% or comprehensive legislation in force at the moment of the study); city of Buenos Aires, Tandil, Mar del Plata (partial smoking restriction), Olavarría, La Plata, Morón, (no legislation). In Bahía Blanca (Buenos Aires), Neuquén (Neuquén), Godoy Cruz and Mendoza (Mendoza) we performed measurements before and after the implementation of the $100 \%$ smokefree legislation.

\section{Training of data collection staff}

Participating researchers completed the training module from the web-based training course located at http:/ / www.tobaccofreeair.org. This training module included step-by-step instructions on the operation of the air monitoring equipment, study protocol and data management. All instructions were first translated into Spanish and were delivered to all participating locations. Project researchers at RPCI provided technical support via telephone and email.

\section{Measurement protocol}

We followed the standard measurement protocol designed by the RPCI described at http: / / www.tobaccofreeair.org and used in previous studies. ${ }^{15}$ Establishments were tested for a minimum of 30 minutes. The number of people inside the venue and the number of burning cigarettes were recorded every 15 minutes during sampling. These observations were averaged over the time inside the venue to determine the average number of people on the premises and the average number of burning cigarettes. For most establishments, a sonic measure (Zircon Corporation, Campbell, CA) was used to measure room dimensions and hence the volume of each of the venues. When using the sonic measure to calculate room dimensions was not possible, room measurements were made through estimation. The average smoker density (ASD) or average number of burning cigarettes per $100 \mathrm{~m}^{3}$ was calculated for each establishment.

In each establishment, respirable suspended particles (RSP) were measured using a TSI SidePak AM510 Personal Aerosol Monitor (TSI, Inc., St. Paul, MN, USA). The SidePak uses a built-in sampling pump to draw air through the device where the particulate matter in the air scatters the light from a laser. The mass concentration of particles is not measured directly but instead is determined by the amount of light scattering. This portable light-scattering aerosol monitor was fitted with a $2.5 \mu \mathrm{m}$ impactor in order to measure the concentration of particulate matter with a mass-median aerodynamic diameter less than or equal to $2.5 \mu \mathrm{m}$, or $\mathrm{PM}_{2.5}$. Tobacco smoke particles are almost exclusively less than $2.5 \mu \mathrm{m}$ with a mass-median diameter of $0.2 \mu \mathrm{m}$. The SidePak was used with a calibration factor setting of 0.32 , suitable for secondhand smoke and used in previous studies of SHS exposure. ${ }^{15-19}$ 
The equipment was set to a one-minute log interval, which averages the previous 60 one-second measurements. The SidePak was zero-calibrated prior to each use by attaching a HEPA filter according to the manufacturer's specifications. Sampling was discreet in order not to disturb the occupants' normal behavior. The monitor was generally located in a central location on a table or bar and not on the floor so the air being sampled was within the occupants' normal breathing zone. For each venue, the first and last minute of logged data were removed because they are averaged with outdoors and entryway air. The remaining data points were averaged to provide an average $\mathrm{PM}_{2.5}$ concentration within the venue.

\section{Statistical analysis}

Data were stratified according to the type of legislation, type of venue (bars, restaurants, discos and pubs) and according to the time of the day (daytime and nighttime). Comparisons were also made between pre- and post law sampling in Bahía Blanca, Neuquén, and Godoy Cruz. Due to the non-normal distribution of the $\mathrm{PM}_{2.5}$ data the non-parametric Mann Whitney Test was used for statistical comparisons. All tests are two-tailed with an alpha of 0.05 . All $\mathrm{PM}_{2.5}$ values in this paper are in micrograms per cubic meter $\left(\mu \mathrm{g} / \mathrm{m}^{3}\right)$.

\section{Results}

We collected 554 samples in 15 cities, 175 with 100\% smokefree legislation (33 in Santa Fe, 30 in Rosario, 21 in Tucumán, 30 in Neuquén, 34 in Bahía Blanca and 27 in Corrientes), 66 with comprehensive smokefree policies (36 in Córdoba, 14 in Mendoza, 16 in Godoy Cruz), and 154 with DSAs (52 in Mar del Plata, 62 in Buenos Aires, 17 in Mendoza City and 23 in Tandil) and 158 in cities without legislation (29 in La Plata, 15 in Morón, 37 in Bahía Blanca, 30 in Neuquén, 25 in Godoy Cruz, 22 in Olavarria). In the cities of Bahía Blanca, Godoy Cruz, Mendoza and Neuquén we performed pre- and post law measurements. Table I shows all measurements conducted in the participating cities and particle concentration levels in all venues.

\section{Cities with $100 \%$ and comprehensive smokefree legislation}

We measured mean particle concentration in the 5 cities that had already introduced $100 \%$ or comprehensive smokefree legislation at the moment of the initiation of our study: Santa Fe, Rosario, Córdoba, Tucumán, and
Corrientes. We observed a high level of compliance except in pubs and discos late at night where compliance was significantly lower (Figure 1). From the 33 measurements performed in the city of Santa Fe, 19 performed during daytime showed mean concentration levels of $44 \mathrm{PM}_{2.5}$ while 14 measurements performed at night showed mean particle concentration levels of 109 $\mathrm{PM}_{2.5}$. In Rosario, 24 measurements performed during daytime showed mean particle concentration levels of $22 \mathrm{PM}_{2.5}$ versus $212 \mathrm{PM}_{2.5}$ obtained in 6 venues late at night. In the city of Córdoba, 5 measurements performed during daytime showed mean concentration levels of 11 $\mathrm{PM}_{2.5}$ versus 31 measurements performed late at night that showed mean particle concentration levels of 150 $\mathrm{PM}_{2.5}$. Across all 5 cities the mean $\mathrm{PM}_{2.5}$ level was 24 during the day (before 8:00 PM) and 98 in the evening (after 8:00 PM). This difference is statistically significant $(p=.012)$ and is consistent with the difference in average smoking density between day ( 0.01 burning cigs per $100 \mathrm{~m}^{3}$ ) and night (1.79).

Pre and post measurements were performed in the cities of Neuquén, Bahía Blanca and Godoy Cruz. We performed 37 pre law and 34 post law measurements in Bahía Blanca, 30 pre and 30 post law measurements in Neuquén, and 25 pre and 16 post law measurements in Godoy Cruz. Sampling was done in the same venues before and after the law but due to logistical issues not all of the places were re-visited during post-law sampling. Pre law measurements showed $\mathrm{PM}_{2.5}$ levels of 126 in Bahía Blanca, 37 in Godoy Cruz, and 47 in Neuquén. After the implementation of $100 \%$ smokefree legislation these levels dropped to 5 in Bahía Blanca, 13 in Godoy Cruz and 5 in Neuquén (Figure 2). The difference in $\mathrm{PM}_{2.5}$ levels from pre- to post law was statistically for all three cities ( $p<0.001$ for each).

\section{Cities with partial smoking restriction}

Cities with partial smoking legislation had higher $\mathrm{PM}_{2.5}$ levels as compared to those with $100 \%$ smokefree venues: city of Buenos Aires $\left(53 \mathrm{PM}_{25}\right)$, Mar del Plata (57 $\mathrm{PM}_{2.5}$ ), Mendoza (pre law) $\left(21 \mathrm{PM}_{2.5}\right.$ ), and Tandil (10 $\mathrm{PM}_{2.5}$. In the city of Buenos Aires we performed 62 measurements. In 40 smokefree venues (without DSAs) the mean concentration level was $35 \mathrm{PM}_{2.5}$ in 22 venues with DSAs we found mean particle concentration levels of 87 $\mathrm{PM}_{2.5}$. From these 22, 12 had structurally separated DSAs where we measured both smoking and non-smoking areas. Mean particle concentration levels were $104 \mathrm{PM}_{2.5}$ in smoking areas vs. $80 \mathrm{PM}_{2.5}$ in non-smoking areas (this difference was not statistically significant, $p=0.272$ ). In addition, the non-smoking areas had significantly higher 
Table I

\section{SUMMARY OF MEASUREMENTS PERFORMED IN ALL CITIES}

$$
\begin{array}{cccccc}
\text { N Smoking observed (N) } & \text { Average } & \text { Daytime / nighttime } & \text { Ratio of smoking/ } & P M_{25} \text { ratio smoking/ } \\
\text { Yes } & \text { No } & P_{25} & \text { measurements }(n)^{*} & \text { smokefree venues } & \text { smokefree }
\end{array}
$$

$100 \%$ smokefree cities

Rosario (April-May 2007)

\begin{tabular}{lrrrrrl} 
Total & 30 & 4 & 26 & 60 & $24 / 6$ & 0.15 \\
\hline Bars & 18 & 0 & 18 & 20 & $17 / 1$ & 0 \\
\hline Restaurants & 5 & 0 & 5 & 17 & $3 / 2$ & 0 \\
\hline Discos/pubs & 7 & 4 & 3 & 193 & $4 / 3$ & 1.33
\end{tabular}

Santa Fe (June-July 2007)

\begin{tabular}{lllllrl} 
Total & 33 & 3 & 30 & 71 & $19 / 14$ & 0.1 \\
\hline Bars & 19 & 2 & 17 & 71 & $12 / 7$ & 0.12 \\
\hline Restaurants & 14 & 1 & 13 & 72 & $7 / 7$ & 0.08
\end{tabular}

Corrientes (Dec 2007-Jan 2008)

\begin{tabular}{lrrrrrl} 
Total & 27 & 3 & 24 & 18 & $10 / 17$ & 0.12 \\
\hline Bars & 13 & 2 & 11 & 19 & $7 / 6$ & 0.18 \\
\hline Restaurants & 10 & 1 & 9 & 20 & $1 / 9$ & 0.11 \\
\hline Discos/pubs & 2 & 0 & 2 & 14 & $1 / 1$ & 0 \\
\hline Gambling establishments & 2 & 0 & 2 & 10 & $1 / 1$ & 0
\end{tabular}

Tucumán (May 2008)

\begin{tabular}{lrrrrrl} 
Total & 21 & 2 & 19 & 7 & $8 / 13$ & 0.10 \\
\hline Bars & 16 & 2 & 14 & 8 & $7 / 9$ & 0.14 \\
\hline Restaurants & 2 & 0 & 2 & 6 & $1 / 1$ & 0 \\
\hline Discos/pubs & 3 & 0 & 3 & 5 & $0 / 3$ & 0
\end{tabular}

Bahía Blanca (post legislation) (Dec 2007)

\begin{tabular}{lccccrc} 
Total & 34 & 0 & 34 & 5 & $18 / 16$ & 0 \\
\hline Bars & 20 & 0 & 20 & 5 & $13 / 7$ & 0 \\
\hline Restaurants & 10 & 0 & 10 & 6 & $4 / 6$ & 0 \\
\hline Discos-Pubs & 3 & 0 & 3 & 4 & $0 / 3$ & 0 \\
\hline Gambling establishments & 1 & 0 & 1 & 1 & $1 / 0$ & 0
\end{tabular}

Neuquén (post legislation) (March 2008)

\begin{tabular}{lcccccc} 
Total & 30 & 0 & 30 & 5 & $9 / 21$ & 0 \\
\hline Bars & 17 & 0 & 17 & 6 & $6 / 11$ & 0 \\
\hline Restaurants & II & 0 & II & 3 & $2 / 9$ & 0 \\
\hline Discos-pubs & I & 0 & I & I & $1 / 0$ & 0 \\
\hline Gambling establishments & I & 0 & I & 5 & $0 / 1$ & 0
\end{tabular}

\section{Cities with comprehensive legislation}

Córdoba (exclusion of discos) (Oct-Dec 2007)

\begin{tabular}{lrrrrrl} 
Total & 36 & 25 & 11 & $|3|$ & $5 / 3 \mid$ & 2.27 \\
\hline Bars & 12 & 5 & 7 & 87 & $4 / 8$ & $0.7 \mid$ \\
\hline Restaurants & 7 & 4 & 3 & 20 & $1 / 6$ & 1.33 \\
\hline Discos/pubs & 17 & 16 & 1 & 207 & $0 / 17$ & 16
\end{tabular}


(Continued)

Mendoza post legislation (Oct 2008-Jan 2009)

\begin{tabular}{lrrrrrl} 
Total & 14 & 1 & 13 & 9 & $11 / 3$ & 0.07 \\
\hline Bars & 10 & 0 & 10 & 7 & $9 / 1$ & 0 \\
\hline Restaurants & 4 & 1 & 3 & 15 & $2 / 2$ & 0.33
\end{tabular}

3.8

Godoy Cruz post legislation (Oct 2008-Jan 2009)

\begin{tabular}{lcccccl} 
Total & 16 & 6 & 10 & 13 & $7 / 9$ & 0.6 \\
\hline Bars & 10 & 2 & 8 & 9 & $5 / 5$ & 0.25 \\
\hline Restaurants & 4 & 2 & 2 & 9 & $2 / 2$ & $\mathrm{I}$ \\
\hline Discos/pubs & $\mathrm{I}$ & $\mathrm{I}$ & 0 & 9 & $0 / 1$ & $\mathrm{n} / \mathrm{a}$ \\
\hline Gambling establishments & $\mathrm{I}$ & $\mathrm{I}$ & 0 & 69 & $0 / 1$ & $\mathrm{n} / \mathrm{a}$
\end{tabular}

\section{Cities with DSN}

City of Buenos Aires (Feb - March 2007)

\begin{tabular}{lrrrrrl} 
Total & 62 & 24 & 38 & 53 & $37 / 25$ & 0.63 \\
\hline Bars & 29 & 6 & 23 & 44 & $19 / 10$ & 0.26 \\
\hline Restaurants & 19 & 8 & 11 & 37 & $16 / 3$ & 0.72 \\
\hline Discos/pubs & 12 & 9 & 3 & 95 & $1 / 11$ & 3 \\
\hline Gambling establishments & 2 & $\mathrm{I}$ & $\mathrm{I}$ & 84 & $\mathrm{I} / \mathrm{I}$ & $\mathrm{I}$
\end{tabular}

Mendoza pre legislation (Nov 2007)

\begin{tabular}{lrrrrrr} 
Total & 18 & 2 & 16 & 21 & $12 / 6$ & 0.12 \\
\hline Bars & 13 & 1 & 12 & 19 & $10 / 3$ & 0.08 \\
\hline Restaurants & 5 & 1 & 4 & 27 & $2 / 3$ & 0.25
\end{tabular}

Mar de Plata (Dec 2007 - Jan 2007 )

\begin{tabular}{lrrrrrl} 
Total & 52 & 31 & 21 & 57 & $25 / 27$ & 1.47 \\
\hline Bars & 19 & 9 & 10 & 16 & $16 / 3$ & 0.9 \\
\hline Restaurants & 22 & 14 & 8 & 45 & $8 / 14$ & 1.75 \\
\hline Discos-pubs & 2 & 2 & 0 & 41 & $0 / 2$ & n/a \\
\hline Gambling establishments & 9 & 6 & 3 & 52 & $1 / 8$ & 2
\end{tabular}

Tandil (April 2008)

\begin{tabular}{lcccccc} 
Total & 23 & 6 & 17 & 10 & $16 / 7$ & 0.35 \\
\hline Bars & 13 & 3 & 10 & 12 & $12 / 1$ & 0.3 \\
\hline Restaurants & 6 & 2 & 4 & 6 & $2 / 4$ & 0.5 \\
\hline Discos/pubs & 3 & 1 & 2 & 7 & $2 / 1$ & 0.5 \\
\hline Gambling establishments & 1 & 0 & 1 & 3 & $0 / 1$ & 0
\end{tabular}

\section{Cities with no legislation}

La Plata (Feb.- March 2007)

\begin{tabular}{lrrrrrl} 
Total & 29 & 27 & 2 & 100 & $13 / 16$ & 13.5 \\
\hline Bars & 13 & 13 & 0 & 43 & $10 / 3$ & $\mathrm{n} / \mathrm{a}$ \\
\hline Restaurants & 8 & 6 & 2 & 75 & $2 / 6$ & 3 \\
\hline Discos/pubs & 6 & 6 & 0 & 242 & $0 / 6$ & $\mathrm{n} / \mathrm{a}$ \\
\hline Gambling establishments & 2 & 2 & 0 & 150 & $1 / 1$ & $\mathrm{n} / \mathrm{a}$
\end{tabular}


(Continued)

\begin{tabular}{lrrrrrl}
$\begin{array}{l}\text { Morón (March 2007) } \\
\text { Total }\end{array}$ & 15 & 13 & 2 & 61 & $13 / 2$ & 6.5 \\
\hline Bars & 8 & 7 & 1 & 51 & $7 / 1$ & 7 \\
\hline Restaurants & 4 & 3 & 1 & 31 & $3 / 1$ & 3 \\
\hline Discos/pubs & 1 & 1 & 0 & 6 & $1 / 0$ & n/a \\
\hline Gambling establishments & 2 & 2 & 0 & 201 & $2 / 0$ & n/a
\end{tabular}

Godoy Cruz (pre legislation) (Nov 2007)

\begin{tabular}{lrrrrrr} 
Total & 25 & 18 & 7 & 37 & $15 / 10$ & 2.57 \\
\hline Bars & 15 & 11 & 4 & 36 & $9 / 6$ & 2.75 \\
\hline Restaurants & 7 & 4 & 3 & 32 & $5 / 2$ & 1.33 \\
\hline Discos/pubs & 2 & 2 & 0 & 40 & $0 / 2$ & $\mathrm{n} / \mathrm{a}$ \\
\hline Gambling establishments & $\mathrm{I}$ & $\mathrm{I}$ & 0 & 86 & $1 / 0$ & $\mathrm{n} / \mathrm{a}$ \\
\hline
\end{tabular}

\begin{tabular}{lcccccc}
\hline Neuquén (pre legislation) (Sept-2007) & & & & & & \\
\hline Total & 30 & 28 & 2 & 47 & $7 / 23$ & 14 \\
\hline Bars & 16 & 15 & $\mathrm{I}$ & 50 & $5 / 1 \mathrm{I}$ & 15 \\
\hline Restaurants & $\mathrm{II}$ & 10 & $\mathrm{I}$ & 44 & $2 / 9$ & 10 \\
\hline Discos/pubs & 2 & 2 & 0 & 45 & $0 / 2$ & $\mathrm{n} / \mathrm{a}$ \\
\hline Gambling establishments & $\mathrm{I}$ & $\mathrm{I}$ & 0 & 46 & $0 / 1$ & $\mathrm{n} / \mathrm{a}$ \\
\hline Bahía Blanca pre legislation (August 2007) & & & & & & \\
\hline Total & 37 & 29 & 8 & 126 & $19 / 18$ & 3.62 \\
\hline Bars & 20 & 17 & 3 & 93 & $13 / 7$ & 5.66 \\
\hline Restaurants & 12 & 7 & 5 & 61 & $5 / 7$ & 1.4 \\
\hline Discos/pubs & 4 & 4 & 0 & 246 & $0 / 4$ & $\mathrm{n} / \mathrm{a}$ \\
\hline Gambling establishments & $\mathrm{I}$ & $\mathrm{I}$ & $\mathrm{I}$ & 462 & $1 / 0$ & $\mathrm{I}$ \\
\hline
\end{tabular}

\begin{tabular}{lrrrrrrl}
\hline Olavarría (May-June 2008) & & & & & & \\
\hline Total & 22 & 22 & 0 & $|3|$ & $2 / 20$ & n/a \\
\hline Bars & 15 & 15 & 0 & 121 & $2 / 13$ & n/a \\
\hline Restaurants & 3 & 3 & 0 & 12 & $0 / 3$ & n/a \\
\hline Discos/pubs & 3 & 3 & 0 & 338 & $0 / 3$ & n/a \\
\hline Gambling establishments & 1 & 1 & 0 & 23 & $0 / 1$ & n/a & $n / a$
\end{tabular}

* Day: 8 AM-8 PM/Night: 8 PM-8 AM

( $p=0.017) \mathrm{PM}_{2.5}$ levels compared to $100 \%$ smokefree venues in the same city (twofold higher).

\section{Cities with no smoking restriction laws}

In general, $\mathrm{PM}_{2.5}$ levels were significantly higher across all cities with no smoking restrictions: Olavarría (131), La Plata (100) and Morón (61). Figure 3 shows an example of an evening of sampling in a city (Olavarría) with no smoking restrictions at the moment of the evaluation. The graph demonstrates high levels of particulate air pollution inside the 4 locations sampled compared to the low outdoor levels seen in between each location visited.

\section{Cities with $100 \%$ or comprehensive smokefree legislation versus cities with no legislation}

Overall, $\mathrm{PM}_{2.5}$ levels were 5 times higher $(p<0.001)$ in cities with no legislation compared to those with $100 \%$ or comprehensive legislation. This includes all venues, whether or not smoking was actually observed. 


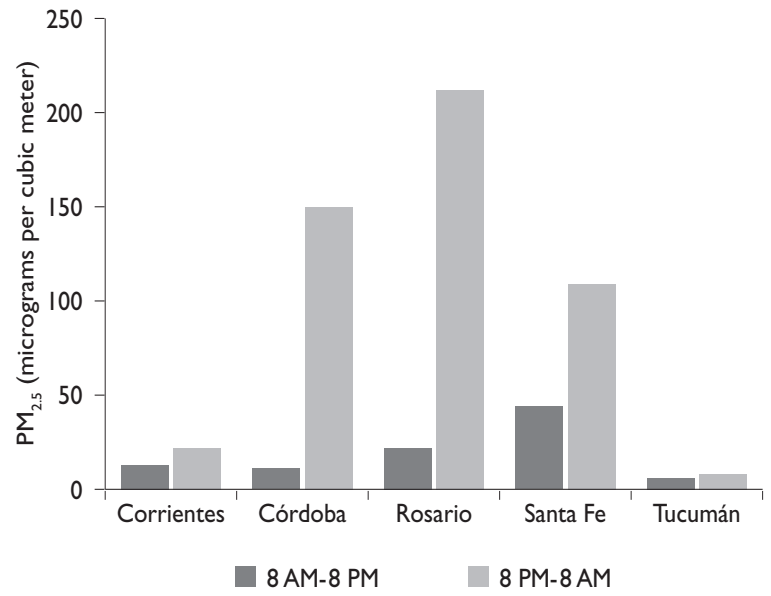

Figure I. Particle air pollution during different TIMES OF THE DAY IN COMPREHENSIVE AND $100 \%$ SMOKEFREE CITIES

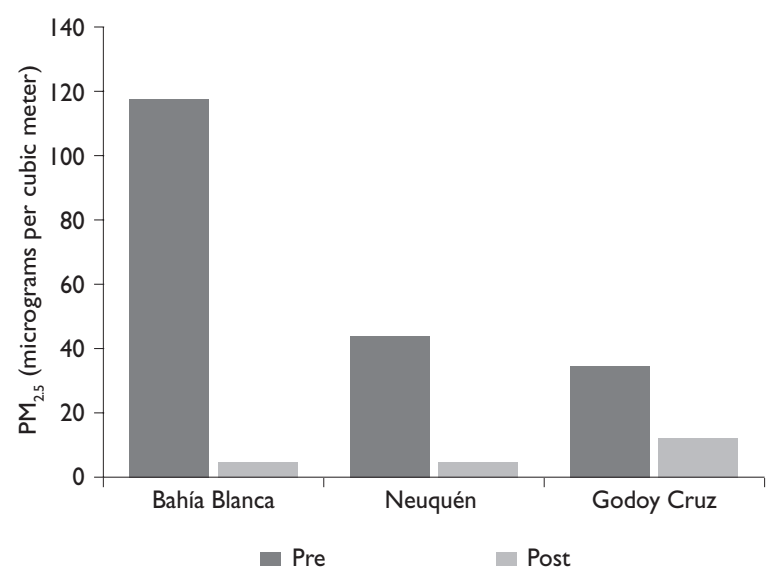

Figure 2. Pre- and post LaW PARTICLE air POLLUTION IN THE cities of Bahía Blanca, Neuquén and Godoy Cruz

Use in advocacy

We organized and conducted press conferences in 8 cities and organized numerous interviews with key local reporters to inform about the results of this study. As a result, over 50 articles containing SidePak measurements were published in national and local newspapers from all over the country. Due to the impact of these publications we were interviewed by numerous radio and TV stations. Moreover, we used SidePak results to advocate for the enactment and enforcement of $100 \%$ smokefree policies according to the local contexts. We organized at least 2 meetings with local legislators to show the results obtained in each participating city.

The impact of such initiatives could be observed in several jurisdictions: in the city of Córdoba, the second most populated city in Argentina (about 1300000 inhabitants) with comprehensive smokefree legislation we observed lack of compliance in pubs and discos late at night. SidePak measurements were used to advocate for the modification of the local ordinance. This was achieved in September 2009, and Córdoba has now introduced a 100\% smokefree legislation with the specific inclusion of discos. SidePak results were also used to develop advocacy strategies to improve compliance in the cities of Santa Fe and Rosario. For venues with partial smoking restrictions our results showed the inefficacy of such measures with contamination levels in nonsmoking areas significantly higher (almost twofold) than those of $100 \%$ smokefree venues. Also, we used SidePak measurements to raise awareness among decision-makers about the need to modify current policies. In Mar del Plata, one of the most popular tourist attractions in Argentina, results were used by local NGOs to promote the introduction of a $100 \%$ smokefree ordinance to modify the current partial restriction policy. In the city of Buenos Aires, a bill has been introduced to modify the current legislation into a $100 \%$ smokefree policy. This project is still under consideration in the local legislature. For places with no legislation we used the results of our study to inform policymakers and to raise public awareness about the need to enact laws to protect the health of the population. In the provinces of Neuquén, Mendoza and in the city of Olavarría (Buenos Aires), data obtained in our study contributed to successfully enact and enforce $100 \%$ smokefree legislation in public places at the local level.

\section{Discussion}

The findings of our study show that most of the participating cities had significantly lower $\mathrm{PM}_{2.5}$ levels after the implementation of $100 \%$ smokefree legislation as compared to cities with no legislation or with partial smoking restrictions. This has also been shown in previous studies. ${ }^{15-18}$

Furthermore, this study shows that 100\% legislation has a high level of compliance in most jurisdictions with a dramatic reduction of SHS exposure in public places. However, pubs and discos from different parts of the country mostly reaching young adults and adolescents remain resistant to the new smokefree legislation and compliance still requires a tailored enforcement strategy. 


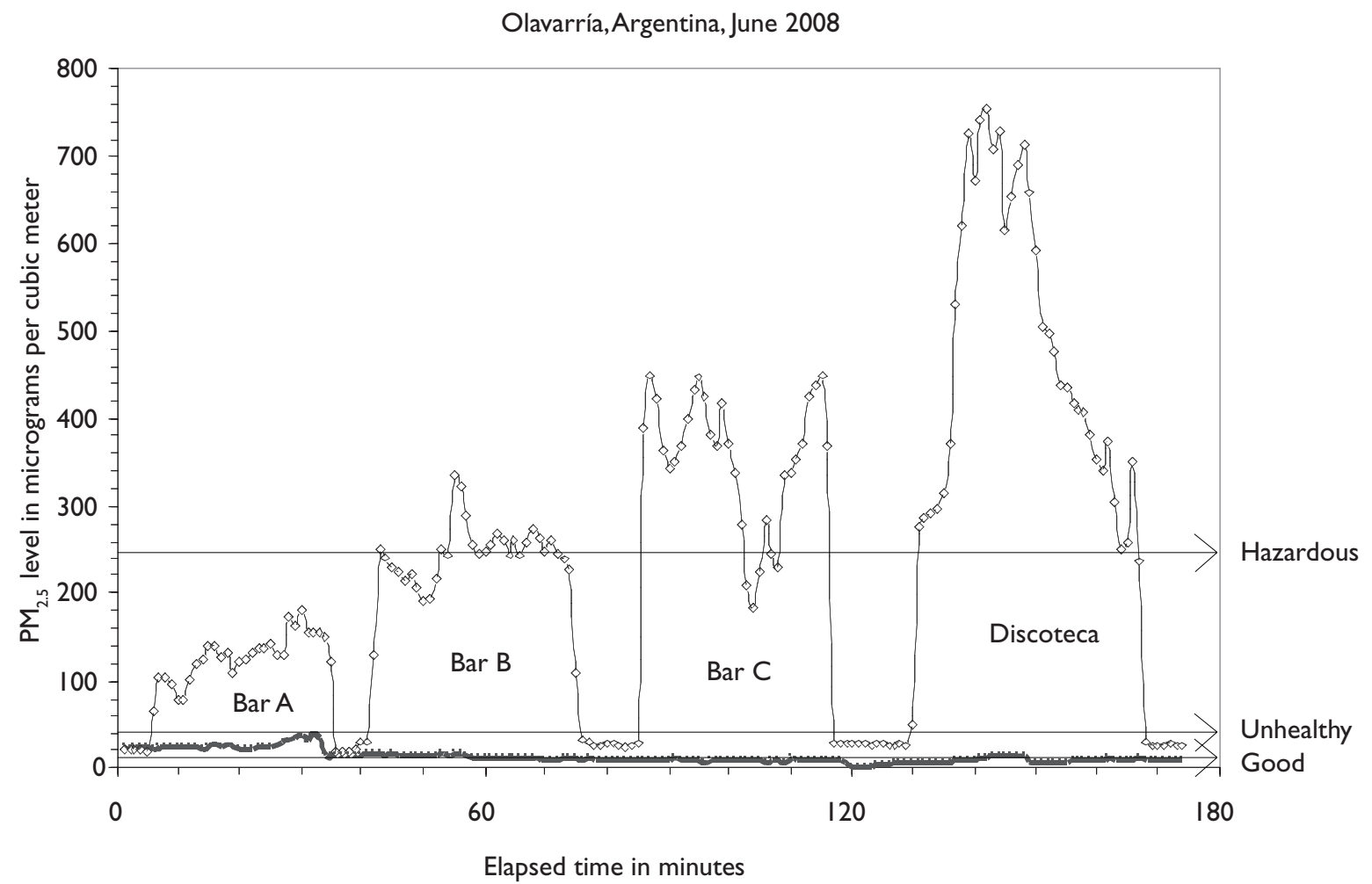

Figure 3. Measurements of air pollution in four VenUes from the city of Olavarría With no legisLation

Lack of compliance during nighttime hours in cities such as Córdoba, Rosario and Santa Fe, is particularly alarming, not only because of the harm caused to hospitality workers exposed to SHS but also because it promotes early smoking initiation among young people. In the cities of Bahía Blanca, Godoy Cruz and Neuquén, where we performed pre- and post law measurements, we observed a significant reduction of indoor air pollution in all venues. Similar results have been shown in other studies. ${ }^{16-18}$

Cities with no smokefree legislation had very high levels of indoor air pollution any time of the day the measurements were performed even exceeding the EPA public health standards by about ten-fold. ${ }^{20}$ As it has already been shown, due to the high prevalence of tobacco consumption and the lack of smokefree legislation in some jurisdictions in Argentina, indoor air pollution in public places was among the highest in the region. ${ }^{21}$

Partial restrictions show low enforcement with significantly higher levels of respirable suspended particles as compared to those observed in smokefree cities. This has also been shown by the opinion poll performed by ALIAR in August 2009 where we observed a significantly lower perception of compliance in jurisdictions with partial restriction laws as compared with $100 \%$ smokefree cities. The city of Buenos Aires showed high $\mathrm{PM}_{2.5}$ concentration levels not only in designated smoking areas but also in designated non-smoking areas when they were compared with smokefree venues. This confirms data published in other studies showing the inefficacy of DSAs as a measure to protect the health of the population. ${ }^{21,22}$

\section{Informing policy debates}

Upon the conclusion of all measurements we developed a strategy to communicate the results of the study. We organized press conferences and published newspaper articles all around the country to inform the results of our study to the media in general and NGOs, the general public and unions in particular. Also, we developed factsheets to inform different policymakers considering their local legislative objectives.

Our study has been significantly useful to advocate for 100\% smokefree legislation in public places in Argentina. The simplicity of the measurement process 
and the accuracy of our results provide a sound tool to raise awareness among local key stakeholders.

The study also provides local evidence to introduce the issue of human rights perspective for workers in the public agenda of a country where SHS has not been considered a risk factor among workers and where there is no legislation to protect the health of all workers at the national level.

Furthermore, ALIAR granted numerous awards to cities with excellent compliance with $100 \%$ smokefree legislation by showing low suspended particle concentration levels. For example, Bahía Blanca, Santa Fe and Neuquén received an award for their commitment to guarantee a high level of compliance with local ordinances.

\section{Limitations}

A limitation to be considered when interpreting our results is the lack of a randomized sample, which could contribute to potential bias of results.

\section{Conclusions}

This study presents local scientific data about the levels of air pollution among the different legislative scenarios and the level of compliance in Argentina. Also, this study was useful to determine air pollution in different types of venues and different times of the day and to develop an effective advocacy strategy to promote legislative changes in Argentina and to implement 100\% smokefree legislation in different jurisdictions.

\section{Acknowledgments}

We thank the organizations from ALIAR that collaborated in the development of this study and all the researchers who performed the measurements in the participating cities: Finkielsztain V, Ortiz Basso T, Nikisch L, Schoj E, Onexyn V, Pérez Cáceres ML, Cuatrocchio V, Dick I, Valeff E, Regueira G, Pérez C, Ruíz E, Otero N, Hasdeu S, Villavicencio L, García C, Parada S, Manrique A, Lungo B, Talamoni J, Bussoli M, Sericcio F, Candioti C, Rivera J, Amato I, Rosende N, Rassmussen R, Kriscovich J, Armendáriz C, Tarcic A, Núñez P, Stock A, Castro Arroyo L, Zuliani M. We also thank Cheryl Higbee from the RPCI team for her assistance in data analysis.

\section{Funding}

This research was funded by the Bloomberg Foundation through a Bloomberg Initiative Grant to promote $100 \%$ smokefree environments in Argentina, and the
Flight Attendant Medical Research Institute (FAMRI) through grants to Roswell Park Cancer Institute. The Bloomberg Foundation and FAMRI played no role in the conduct of the research and the preparation of the manuscript. The InterAmerican Heart Foundation Argentina, the Hospital Italiano de Buenos Aires and other organizations members of ALIAR all around the country provided administrative support and the human resources to carry out the study. The Roswell Park Cancer Institute staff provided the equipment and performed the statistical analyses.

\section{Declaration of conflicts of interest}

We declare that we have no conflicts of interest.

\section{References}

I. US Department of Health and Human Services. The health consequences of involuntary exposure to tobacco smoke: a report of the Surgeon General - Executive Summary.Atlanta, GA: US Department of Health and Human Services, Centers for Disease Control and Prevention, Coordinating Center for Health Promotion, National Center for Chronic Disease Prevention and Health Promotion, Office on Smoking and Health, 2006

2. IARC Monographs on the Evaluation of Carcinogenic Risks to Humans. Tobacco smoke and involuntary smoking. Geneva: International Agency for Research on Cancer (World Health Organization), 2002: 83.

3. California Environmental Protection Agency. Proposed identification of environmental tobacco smoke as a toxic air contaminant. Part B: Health effects. Sacramento, California: California Environmental Protection Agency, Office of Environmental Health Hazard Assessment, 2005. 4.World Health Organization.WHO Framework Convention on Tobacco Control (WHO FCTC). [Accessed I9 May 2010]. Available at: http:// www.who.int/tobacco/framework/en/.

5. Sebrié EM, Schoj V, Glantz SA. Smokefree environments in Latin America: on the road to real change? Prev Control 2008;3(I):2I-35. 6. Global Smoke-free Partnership. [Accessed I5 May 2010]. Available at: http://www.globalsmokefreepartnership.org/.

7. Mejia R, Schoj V, Barnoya J, Flores ML, Pérez-Stable EJ. Tobacco industry strategies to obstruct the FCTC in Argentina. CVD prevention and control 2008;3(4): I73-I79.

8. Sebrié EM, Glantz SA. Local smoke-free policy development in Santa Fe, Argentina. .Tob Control 2010; 19 (2): II0-II6.

9. Schoj V,Alderete M, Ruiz E, Hasdeu S, Linetzky B, Ferrante D. The impact of a $100 \%$ smoke-free law on the health of hospitality workers from the city of Neuquen,Argentina. Tob Control 2010;19(2):I34-137.

10. Sebrié EM, Glantz SA “Accommodating” smoke-free policies: tobacco industry's Courtesy of Choice programme in Latin America. Tob Control 2007; 16 (5):e6.

I I. Sebrié EM, Barnoya J, Perez-Stable EJ, Glantz SA. Tobacco industry successfully prevented tobacco control legislation in Argentina. Tob Control 2005; 14 (5): e2.

12. Barnoya J, Glantz S. Tobacco industry success in preventing regulation of secondhand smoke in Latin America: the "Latin Project". Tob Control 2002; I I (4):305-3 I4.

13. Siegel M, Skeer M. Exposure to secondhand smoke and excess lung cancer mortality risk among workers in the "5 B's": bars, bowling alleys, 
billiard halls, betting establishments, and bingo parlours. Tob Control 2003;12(3):333-338.

14. International Labour Organization Introductory Report: Decent Work - Safe Work. Geneva: International Labour Organization. 2005. [Accessed 28 February 2010]. Available at: http://www.lo.org/public/libdoc/ ilo/2005/I05B09_28I_engl.pdf.

15. Hyland A, Travers MJ, Dresler C, Higbee C, Cummings KM.A

32-country comparison of tobacco smoke derived particle levels in indoor public places. Tob Control 2008; 17(3):159-165.

16. Travers MJ, Cummings KM, Hyland A, Repace JL, Pechacek TF, Caraballo $\mathrm{R}$, et al. Indoor air quality in hospitality venues before and after the implementation of a Clean Indoor Air Law-Western New York, 2003. MMWR Morb Mortal Wkly Rep, 2004;53(44): 1038-104I.

17. Repace JL, Hyde JN, Brugge D. Air pollution in Boston bars before and after a smoking ban. BMC Public Health 2006;6:266.
18. Repace J. Respirable particles and carcinogens in the air of Delaware hospitality venues before and after a smoking ban.J Occup Environ Med 2004:46 (9):887-905.

19. Klepeis NE, Ott WR, Switzer P. Real-time measurement of outdoor tobacco smoke particles. J Air Waste Man Assoc 2007;57 (5):522-534.

20. United States Environmental Protection Agency.Air Quality Index.A Guide to Air Quality and Your Health. [Accessed 3 March 2010]. Available at: http://www.enviroflash.info/assets/pdf/AQI_2003_9-3.pdf.

21. Navas-Acien A, Peruga A, Breysse P, Zavaleta A, Blanco-Marquizo A, Pitarque $R$, et al. Secondhand tobacco smoke in public places in Latin America, 2002-2003. JAMA 2004;29I(22):274I-2745.

22. Chao C. Legislative Council Panel on Health Services Findings of Technical Feasibility Study on Smoking Rooms. [Accessed 5 February 2010]. Available at: http://www.legco.gov.hk/yr08-09/english/panels/hs/ papers/hs0420cb2-1324-5-e.pdf 2009. 